\title{
DESIGNING ENERGY EFFICIENT AND ECOLOGICAL SOLAR HOUSE
}

UDC: $728.3: 697.7$

Review paper

https://doi.org/10.18485/aeletters.2018.3.4.4

\author{
Ivana Stošić ${ }^{1}$, Mumen Abuarkub², Miodrag Šmelcerovićc ${ }^{3}$, Marijana Šmelcerović ${ }^{4}$ \\ ${ }^{1}$ Faculty of Civil Construction Management, University Union "Nikola Tesla", Belgrade, Serbia \\ ${ }^{2}$ Faculty of Architecture, University "Isra", Aman, Jordan \\ ${ }^{3} \mathrm{Higher}$ school of technology and art, Leskovac, Serbia \\ ${ }^{4}$ Higher Public Prosecutor's Office, Leskovac, Serbia
}

\begin{abstract}
:
The goal of the paper is to represent the energy efficient activities on an ecological solar house and to improve its ecological solar compositionality. The subject of this paper is the optimization of energy consumption, insulation capacity, optimization of air and other parameters, all in view of reaching and improving energy efficiency and ecological aspect when designing solar passive houses. Having analysed micro and macro influences and taken into account the energy factors of a parcel of land, the structure is envisioned through the application of an indirect-passive approach, so as to have the passive solar structure simultaneously as a solar collector and heat storage, while the emphasis is put on an optimal, efficient and ecologically functional design. In order to make the process of construction of the ecological solar house a compatible and energy efficient one, constructing the structure with ecological materials is foreseen. In accordance with this, in this paper a representation of the design of the ecological solar house is provided, with the optimal use of solar energy and heat in focus.
\end{abstract}

\section{ARTICLE HISTORY}

Received: 07.10.2018.

Accepted: 21.11.2018.

Available: 31.12.2018.

\section{KEYWORDS}

Solar house, ecological

house, solar energy, heat

\section{INTRODUCTION}

Renewable sources of energy are used for providing less than $1 \%$ of the overall energy produced in the world [1]. Development of renewable sources of energy, and in particular, the energy of wind, water, the Sun and biomass, is the main goal of the energy policy of the European Commission - Department for Energy and Transport of the European Commission. The European Union passed several directives related to renewable sources of energy: the Directive 2001/77/EZ, 2003/30/EZ and 2009/28/EZ. The last directive foresees a target of at least $20 \%$ share of energy from renewable sources in overall Community energy consumption by 2020 . On January $26^{\text {th }}, 2009$, the Republic of Serbia became a member and founder of the International Agency for Renewable Sources of Energy (IRENA), whose main goal is providing precise consulting services to the governments industrialized for the policy of using renewable sources of energy, technology transfer and consultancy services regarding financing of projects, constructing and manufacturing capacities in the field of using renewable energy [2].

On January $3^{\text {rd }}, 2014$, the Government of Serbia passed the Proposal of the energy development strategy until 2025, with projections until 2030, which foresees production of electrical energy from renewable sources. This strategy also foresees reduction in emission of gases and increase of energy efficiency $[1,3]$. As announced by the government of Serbia, the strategy establishes the long-term goals for development of manufacturing capacities of the country, which serve the function of safe procurement and environment, as well as development of 
transmission, transport and distributional system and market of electrical energy and natural gas. The degree of scientific development allows commercial ways of using sources for obtaining energy. Renewable sources of energy comprise of: solar energy, wind energy, biomass (biofuel and biogas), geothermal springs, energy of small water courses, energy of ebb and flow, energy of waves, internal energy of seas and oceans [1]. Supply of energy from renewable energy source (RES) is a key strategic factor of every country because it directly has an influence on lowering negative impact on environment [4]. In the author's study [1] an overview of renewable energy resources in Serbia is given, since many researches shows that Serbia has great potential of RES (renewable energy source). It also has good conditions for heat energy from renewable resources [1]. Solar energy might have a significant place in energy production of one country because it represents renewable and inexhaustible energy resource [3]. Solar energy is from the aspect of ecology pure energy whose energy technology in application is not polluting the environment [5].

For the purpose of this paper solar energy might be accomplished converting solar energy into heat [6]. Solar systems for heat production are used in households and industry (for heating of sanitary water, heating of technical water), heating of water in pools, etc. [7]. The number of sunny days in Serbia is more than 2,000 $\mathrm{h}$ [8]. Vojvodina has resources of solar energy significantly higher than the European average together with good season disposition [1]. Its efficient and long-term use is necessary to design as soon as possible. With more significant use of solar energy, Serbia will come closer to the recommendations of the European community for the use of renewable resources, which include a significant need for more intensive use of solar energy [9].

Our paper examines the application of solar energy in everyday life in the sphere of human residency. In accordance with this, an "eco-passive house" in the territory of Vojvodina is presented, the house which uses solar energy to produce electrical energy and provides heating within it. Materials foreseen for construction are ecological, with proper thermal accumulation and nonacoustic properties. Every hour the Sun emits the amount of energy that the entire population of the Earth uses in a year [10]. Thus, this represents an investment into the permanent solution of heating, the cost of which could not be changed by taxes or global economic or political crisis. What differentiates this type of house from other ecological houses is its innovative design based on solar energy and elements of energy efficiency [11].

\section{FUNCTION MODE OF SOLAR HOUSE}

The technology of construction used in a solar house can be applied to the already existent residential structures, but it is most common to start construction of these houses from foundation, with particular attention paid to putting the local climatic functions into the best use. This implies that solar houses built for specific geographical locations will not be the same, but rather adjusted to the specific climatic conditions. The adjustment is necessary to be applied even in the designing phase. Designing of the solar house presented in this paper is achieved through application of bioclimatic designing for the European area, in the zone of the moderate continental climate, with 4 seasons, and dominant eastern wind. When designing the ecological solar house, the goal was to reach as stabile micro-climate conditions as possible, regardless of the temperatures outside of the house [12]. Through the analysis of micro and macro influences and taking into account the energy factors of the parcel of land, the ecological solar house is designed by the application of an indirect-passive approach, i.e. in accordance with the indirect-passive solar principles and extended with a modern, ecologically functional and energy efficient design (Fig.1).

The basic guiding principle upon designing the ecological solar house is that it should have two functions. The ecological solar house simultaneously represents both a solar collector and a heat storage. The advantage when designing this type of a house is the optimized and reduced consumption of solar energy. This refers in particular to heating and lighting of the ecological house [13]. The technique of the passive solar approach currently represents the best manner of using solar energy, since it does not require the investment of electrical energy. It is largely economical and efficient. Moreover, the technology applied is entirely ecologically adjusted. The passive ecological house is a structure in which internal climate can be adjusted without using active heating or cooling systems [14]. The house, heated or cooled automatically is a "passive" house". For passive buildings in Europe, the definition of an ecological passive house is that the annual consumption of energy related solely to heating would be less than $15 \mathrm{kWh} / \mathrm{m}^{2}$ [15]. This 
type of optimization of heat energy should not be achieved by the increased consumption of another kind of energy, for example electrical energy. In accordance with the research of the authors [15] the consumption of the overall primary energy for all the needs of the living area of a passive house in Europe generally does not exceed $120 \mathrm{kWh} / \mathrm{m}^{2}$ for heating, hot water and electrical energy for the household.

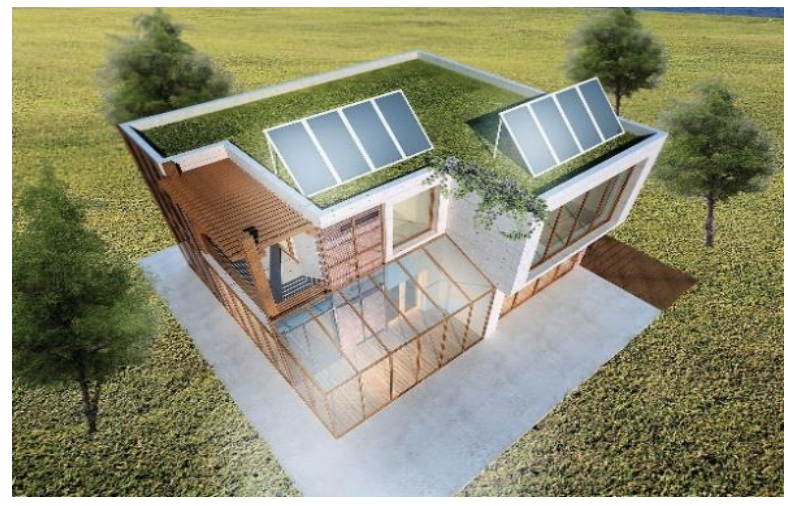

a)

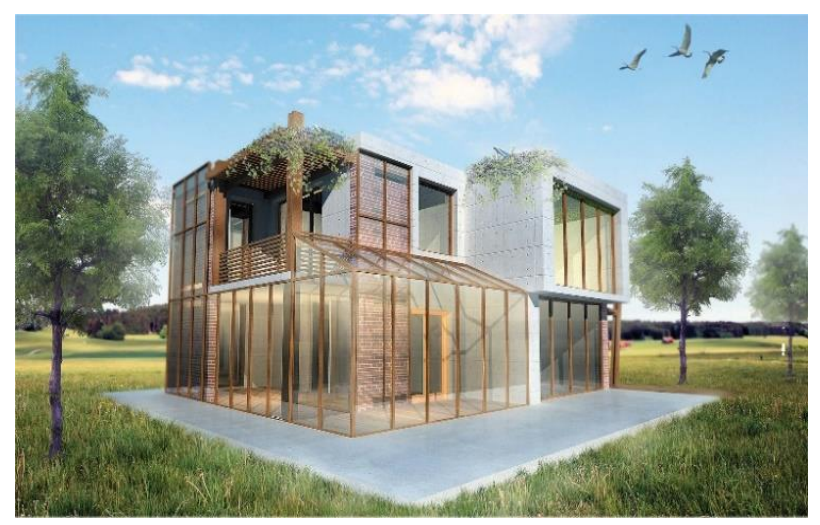

b)

Fig. 1. Projection of ecological solar house a) look from above and b) side view

The designed house is independent, individual on two levels $(P+1)$. On the first level, ground floor, there is a living room, a study room, as well as rooms for storing energy and facility rooms (Fig.2).

On the second level, the first floor, there are bedrooms, facilities and a solar gallery (Fig.3).

The applicable options for the passive use of solar energy are: floor heat storage, heating through air collectors, spectra-selective surface, exterior reflective surface, interior reflective surface, glass veranda, water wall "trans wall". In order to make the entire process of planning and construction sustainable, in the designing phase of the ecological solar house ecological materials have been used with the adequate thermal accumulation and acoustic properties (Fig.4).

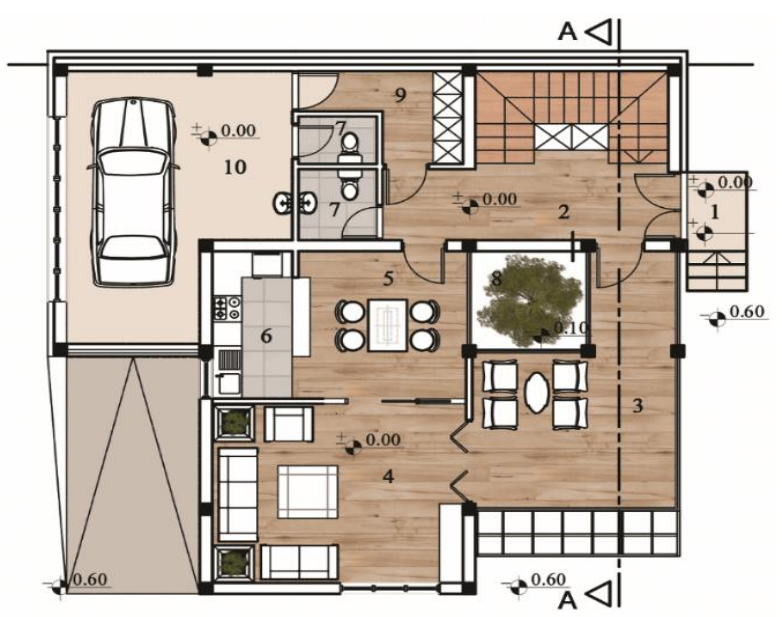

Fig. 2. Ground floor layout

(1- Entrance, 2- Stairs, 3-Solar gallery, 4- Living room, 5Dining room, 6- Kitchen, 7- Toilette, 8- Atrium, 9-

Storage room, 10- Garage)

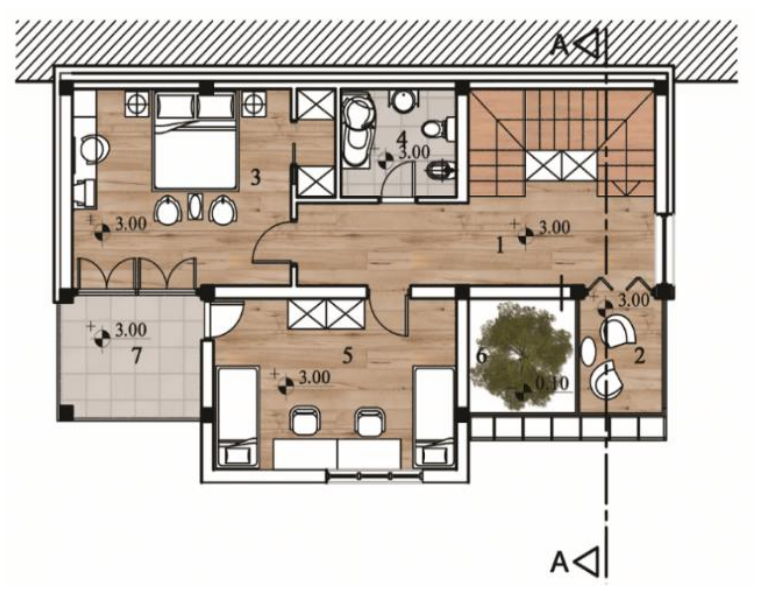

Fig. 3. First floor layout

(1. Stairs, 2- Solar gallery, 3- Master bedroom, 4Bathroom, 5- Nursery, 6- Atrium, 7- Balcony) d) Vertical cross section)

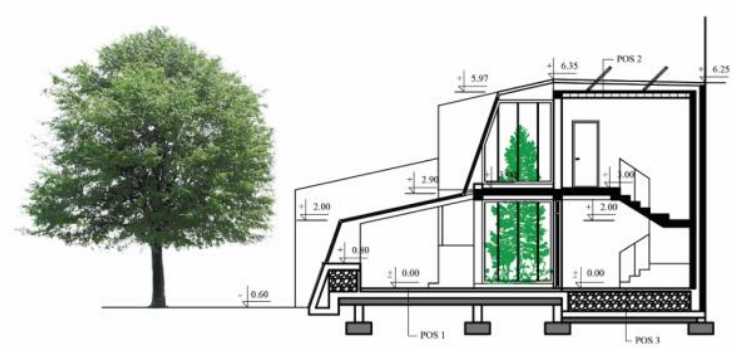

Fig. 4. Vertical cross section

POS 1

Swimming floor, Channel for hot air flow, Thermal isolation, Unarmed concrete, Hydro isolation, Concrete of weaker brands,Tampon gravel, Charged soil. 


\section{POS 2}

Prolonged mortar, Interconnected construction, Layer for a fall, Thermal isolation, Separation layer, Hydro isolation, Protection of waterproofing.

\section{POS 3}

Cement slate, Unarmed concrete, Floor heat storage, Thermal isolation, Unarmed concrete, Hydro isolation, Concrete of weaker brands, Tampon gravel, Charged soil.

The advantage of using these materials is in the fact that these can be recycled. The construction system of the designed ecological solar house is a skeleton one, and the special element, dominant verandas, are executed in thermal glass slanted and in accordance with this, they provide an elongated form of the structure and transparency of the facade. In order to allow a better passivity of the ecological solar house low and three-fold glass has been used and superinsulation frames have been executed without thermal suspension. By this kind of designing of the ecological solar house more natural heat energy is obtained than usual, i.e. better energy heat efficiency is provided. When designing the ecological solar house a method of geometry is applied. This method particularly refers to designing facades in a form of slanted panels placed in the formation of a double shell. The double shell allows circulation of air through stone heat accumulator and its return though the central air compartment into the interior of the object. This principle allows heating in winter, cooling of air in summer in the ecological solar house, resulting in both energy efficiency and energy saving.

\subsection{Scheme of ecological house characteristic stream of hot-cold air in winter period}

During the day the heated air from the air collectors naturally circulates into gravel heating it, and cool air from the gravel passes to the collector. Hot air is from the glass veranda transmitted by fans to the heat storage under the structure's floor. The lids in the rooms are open so the hot air is immediately absorbed in the rooms. Deciduous trees do not prevent passage of sun rays towards the structure (Fig.5a).

During the night the lids in the rooms are open, so that the hot air from the heat storages heats the house rooms. Interior curtains prevent waste of heat. Heating of the solar gallery located on the floor is performed through a glass veranda and a water wall called "trans wall". During the day the entire volume of water absorbs sun rays, while during the night the heat is transmitted to the interior of the house [16]. During the winter period heat is also partially absorbed during the day (Fig.5b).

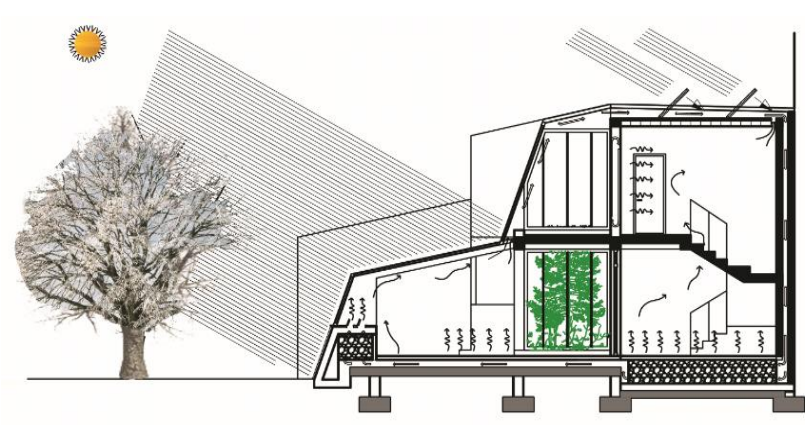

a)

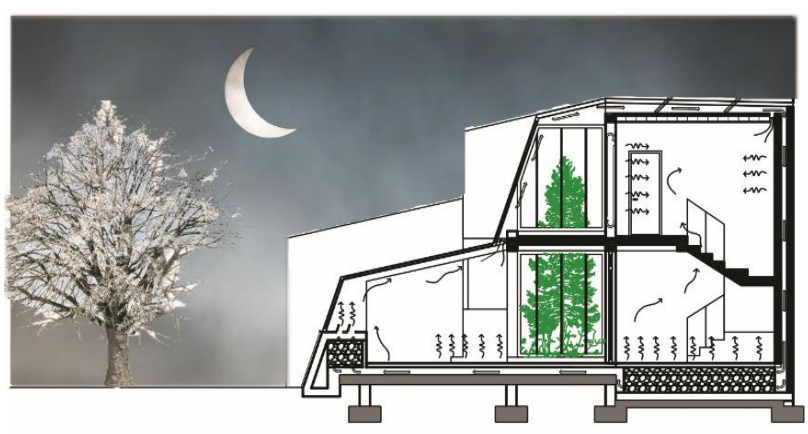

b)

Fig. 5. Scheme of ecological house characteristic stream of hot-cold air in winter period

a) Day and b) Night

\subsection{Scheme of ecological house characteristic stream of hot-cold air in summer period}

In the summer period during the day, as in winter, the heated air from the air collectors circulates into gravel, and cool air from the gravel passes to the collector. The transmission of the heat from the glass veranda by means of the heat storage is identical to the one of the winter period. Hot air naturally heated in the rooms by natural circulation passes through the glass veranda and the channels for air stream and is partly stored in the layer of gravel under the floor of the structure, and partly is discarded through windows [9]. Curtains, deciduous trees, heat inertness of large masses, and natural ventilation prevent overheating (Fig.6a). During the night the lids in the rooms are open, so the hot air from the heat storages heats the house rooms. Thus, the gravel radiates heat and warms the room, while the cool air passes to the grass veranda (Fig.6b). 


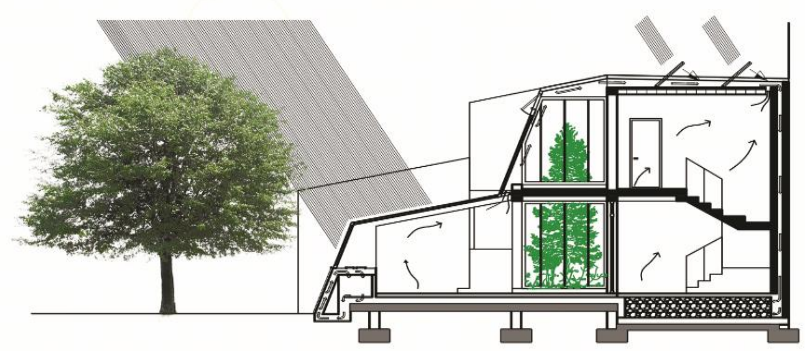

a)

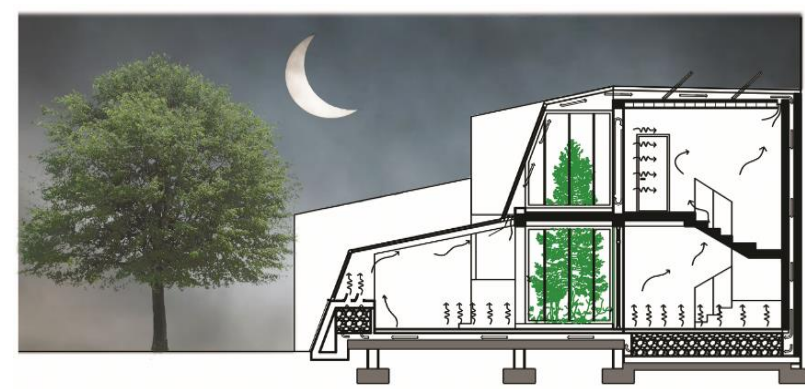

b)

Fig. 6. Scheme of ecological house characteristic stream of hot-cold air in summer period

a) Day, b) Night

\section{THE PROCEDURE OF PASSIVE SOLAR APPROACH}

The principles of the passive solar approach have been mentioned in the previous part of the text. In the designing phase of the ecological solar house some of the following principles proved as energy efficient have been applied. River gravel deposited below the house floor has been used as the ground storage of heat. Hot air from the glass veranda is, by means of fans, transmitted to the gravel under the floor of the room in accordance with the paper od the author [17]. Warm gravel emits heat into the room, while the cool air during the night returns to the glass veranda (Fig.7a, detail 1). During the day the heated air from the air collectors naturally circulates into the gravel heating it, and cool air from the gravel passes into the collector. On this occasion the openings on the surface in the interior of the room are closed, which is the recommendation of the author [18]. During the night or winter, the lids in the room are open, so the warm air from the storage heats the living rooms (Fig.7a, detail 2). During the day the selective surface collects heat with the minimal wastes of $3-5 \%$. The heat contained is during the night released into the object by the surface (Fig.7a, detail 3). The interior reflective surface is set under the glass surfaced in the south, on the ground floor which was found as optimal in the author's work [19]. As in the research of the author
[20] the reflective surface is made of special materials that reflect light. Its role is to increase the amount of sun rays on the solar collectors during the winter period and thus lead to better heating of the object and energy saving (Fig.7a, detail 4). The exterior reflective surface is of the same role as the interior one, its role being to increase the amount of sun rays in the house in the winter period and heat it thereof [21] (Fig.7a, detail 5). Glass veranda, as an integral part of the solar architecture, is set in the south of the ecological solar house. By means of a glass veranda the direct and diffuse sun rays approach is conducted, which is proved efficient [22]. Warm air from it is by fans transmitted to the heat storage (Fig.7b, detail 6). The water wall within the ecological solar house had a role of absorption of sun rays and storage of heat and is proved efficient [23]. During the day the entire volume of water absorbs sun rays, while during the night the radiance is emitted to the interior of the house, thus leaning to energy savings [24], (Fig.7b, detail 7).

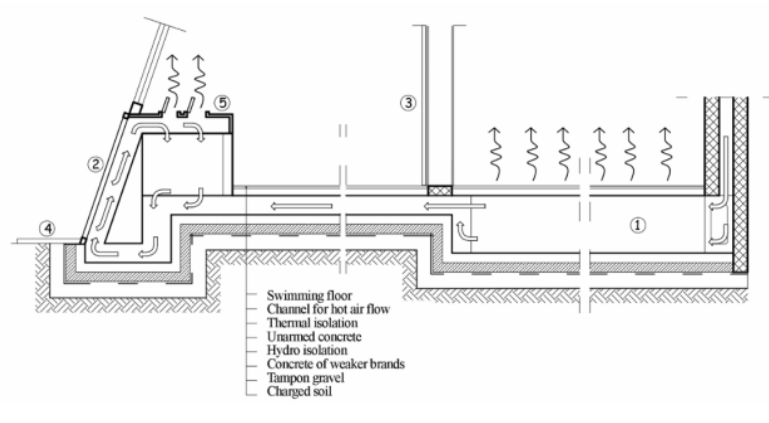

a)

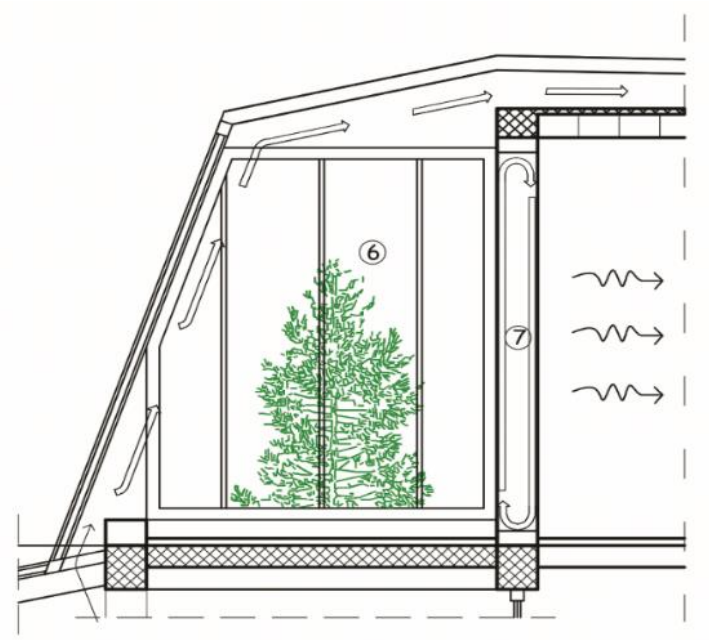

b)

Fig. 7. Passive solar approach

a) 1-Groung heat storage, 2- Heating through air collectors, 3- Spectral-selective surface, 4- Exterior reflective surface, 5 - Interior reflective surface b) 6- Glass veranda, 7- Water wall "trans wall" 


\section{DISCUSSION AND FUTURE RESEARCH}

The result of the designing and construction of the ecological solar house presented in this paper is significant saving of heat and solar energy. A significant role is ascribed to the implementation of ecological materials, with the possibility of recycling, as well as the application of the optimal designing principles and methods elaborated on in the previous part of the text. The ecological solar house designed in accordance with the provided principles would last longer. Key reasons for building an ecological solar house in Vojvodina are:

> Over $55 \%$ of all energy consumption is consumed in households in the form of electricity, out of which a big part is used for sanitation water heating [1];

> Costs for sanitation water heating are reduced for around $60-70 \%$ annually, which leads to better household revenues [1];

$>$ Increased employment in the area of building and servicing of solar ecological house;

> By building ecological solar houses, we are getting closer to the norms of European community about the ecological point of view and with uses of solar energy.

The positive characteristics of designing and construction ecological solar house, apart from those stated in the previous part of the text, are financial and economic savings. Taking into account that the ecological materials and solar energy are used, financial savings are achieved. Besides, the advantage is that with designing and construction of such a structure an ecologically healthy residential area is obtained. The particular attention is put on natural cleaning of air in the rooms of ecological solar house. This is achieved with a minimal application of glass shells in the form of frames. One of the negative characteristics of designing ecological solar houses is related to the particularities of the choice of location. Taking into account that the construction of this type of object represents improvement of a common residential area, occasionally its construction requires more time. In addition, the calculations need to be performed with significant precision and all this requires the engagement of experts. Small discrepancies during construction can lead to big loses in terms of money and time. Also, in the construction phase of ecological solar house it is necessary to timely procure the optimal supply of recycling materials. The shortcomings of designing the ecological solar house are: the lack of funds for financing of building installation, low understanding of possibilities and uses of solar energy, low information level in the population about the possible application of energy of the Sun, prices of the equipment, energy, and economic effects, low economy standard in Serbia, relatively low prices of electric energy.

\section{CONCLUSION}

This paper provides a representation of designing energy efficient and ecologically passive solar house in view of improving the common residential area in the variety of aspects. The goal is to improve the residential area in terms of energy and ecology. This paper presents the basic principles and methods of designing such a type of residential structure. The particular attention has been paid to savings of energy, both solar and heat one. Also, the focus has been put on the ecological aspect of the designing of a solar passive house. This particularly applies to usage of material which can be recycled and reused. In accordance with this, there are also financial benefits gained. Apart from the aspects of energy, ecology and finances, this paper focuses on economic viability of construction of an ecological solar house which proved optimal. The choice of the location in this paper proved optimal and applicable to all the elements necessary for successful and energy efficient construction of this type of residential structure. In the end, the conclusion can be reached that the designed solution successfully complied with all the requests set.

\section{REFERENCES}

[1] S. Prvulovic, Lj. Josimovic, M. Matic, D. Tolmac, Lj. Radovanovic, Resource potential and scope of the use of renewable energy sources in Serbia. Energy Sources, Part B: Economics, Planning, and Policy, 11 (10), 2016: 901-910.

https://doi.org/10.1080/15567249.2013.791898

[2] REN21, Renewables Global Status Report (2006-2011.) Available at:

http://www.ren21.net/

[3] Q. Liu, G. Yu, J.J. Liu, Solar radiation as largescale resource for energy - short world. Energy \& Environment, 20 (3), 2009: 319-329.

https://doi.org/10.1260/095830509788066466

[4] M. Lambić, D. Lambic Heat characteristics of massive solar walls. Energetic Tehnologies : 
Journal for Scientists and Engineers, 5 (3), 2008: 3-7.

[5] M. Lambić, N. Pavlović, I. Tasić, D. Stojićević, Solar energy - installations and facilities. Solar Serbian, Zrenjanin, 2006.

[6] F. Softic, A. Stjepanovic, Z. Bundalo, Temperature characteristics and energy efficiency of solar cells and solar modules. 2012 Mediterranean Conference on Embedded Computing (MECO), 19-21 June 2012, Bar, Montenegro, pp.288-291.

[7] A. Ašonja, The Potential of Solar Energy in the Republic of Serbia : Current Situation, Possibilities and Barriers. Applied Engineering Letters, 3 (3), 2018: 90-97.

https://doi.org/10.18485/aeletters.2018.3.3.2

[8] A. Ašonja, J. Pekez, N. Janjić, D. Mikić, The Validity for the Application of Solar Energy in Irrigation of Perennial Plants in Fruit Growing in the Republic of Serbia. Applied Engineering Letters, 1 (3), 2016: 85-90.

[9] J. Pekez, Lj., Radovanovic, E. Desnica, M. Lambic, The increase of exploitability of renewable energy sources. Energy Sources, Part B: Economics, Planning, and Policy, 11 (1), 2016: 51-57.

https://doi.org/10.1080/15567249.2011.580318

[10] K.T. Huang, R.L. Hwang, Future trends of residential building cooling energy and passive adaptation measures to counteract climate change: the case of Taiwan. Applied Energy, $184(-), 2016:$ 1230-1240.

https://doi.org/10.1016/i.apenergy.2015.11.008

[11] B. Su, The impact of passive design factors on house energy efficiency. Architectural Science Review, 54 (4), 2011: 270-276.

https://doi.org/10.1080/00038628.2011.613638

[12] A.M. Omer, Energy, environment and sustainable development. Renewable and Austainable Energy Reviews, 12 (9), 2008: 2265-2300.

https://doi.org/10.1016/j.rser.2007.05.001

[13] A. Demirbaş, Energy conservation and storage systems. Energy Exploration \& Exploitation, 20 (5), 2002: 391-399.

https://doi.org/10.1260/014459802321146992

[14] H.F. Kaan, B.J. de Boer, Passive houses: achievable concepts for low $\mathrm{CO}_{2}$ housing. In ISES conference, September 2005, Orlando, USA.

[15] J. Schnieders, CEPHEUS-measurement results from more than $100 \mathrm{dwelling}$ units in passive houses. European Council for an Energy Efficient Economy: Summer Study, 2003.

[16] X. Song, W. Gao, T. Liu, W. Lin, M. Li, C. Luo, The operational thermal performance of a simple passive solar house in winter: a case study in Kunming, China. International journal of green energy, 10 (6), 2013: 647-660.

https://doi.org/10.1080/15435075.2012.726672

[17] M.F. Demirbas, Thermal energy storage and phase change materials: an overview. Energy Sources, Part B: Economics, Planning, and Policy, 1 (1), 2006: 85-95.

https://doi.org/10.1080/009083190881481

[18] M. Olenets, J.Z. Piotrowski, A. Stroy, Heat transfer and air movement in the ventilated air gap of passive solar heating systems with regulation of the heat supply. Energy and Buildings, 103 (-), 2015: 198-205.

https://doi.org/10.1016/i.enbuild.2015.05.051

[19] V. Devabhaktuni, M. Alam, S.S.S.R. Depuru, R.C. Green II, D. Nims, C. Near, Solar energy: Trends and enabling technologies. Renewable and Sustainable Energy Reviews, 19 (-), 2013: 555-564.

https://doi.org/10.1016/i.rser.2012.11.024

[20] P. De Laquil III, D. Kearney, M. Geyer, R. Diver, Solar-thermal electric technology. Renewable Energy: Sources for Fuels and Electricity, 1993, p.213-296.

[21] H. Chang, Y. Liu, J. Shen, C. Xiang, S. He, Z. Wan, S. Shu, Experimental study on comprehensive utilization of solar energy and energy balance in an integrated solar house. Energy Conversion and Management, 105 (-), 2015: 967-976.

https://doi.org/10.1016/j.enconman.2015.08.061

[22] E. Mlecnik, Innovation development for highly energy-efficient housing: Opportunities and challenges related to the adoption of passive houses. IOS Press, Amsterdam, The Netherlands, 2013.

[23] O. Saadatian, K. Sopian, C.H. Lim, N. Asim, M.Y. Sulaiman, Trombe walls: a review of opportunities and challenges in research and development. Renewable and Sustainable Energy Reviews, 16 (8), 2012: 6340-6351.

https://doi.org/10.1016/i.rser.2012.06.032

[24] M. Rabani, V. Kalantar, A.A. Dehghan, A.K. Faghih, Experimental study of the heating performance of a Trombe wall with a new design. Solar Energy, 118 (-), 2015: 359-374.

https://doi.org/10.1016/i.solener.2015.06.002 